\title{
Výjimečný divadelní počin: Mejerchold (představení Divadelního Studia Marta Janáčkovy Akademie múzických umění)
}

Michaela Hashemi

(Brno, Česká republika)

Premiéra: 5. 12. 2019. Autor scénáře: Jakub Kostelník; dramaturgie: Libor Brzobohatý; výprava: Magdaléna Paráčková-Teleky; hudba: Richard Dvořák; pohybová spolupráce: Adam Mašura; režie: Jan Antonín Pitínský.

Hrají: Eliška Brumovská, Klára Bulantová, Hana Drozdová, Štěpánka Romová, Eliška Vocelová, Matěj Beneš, Šimon Bilina, Lukáš Dohodil, Johnny Horák, Jaromír Chmelař, Filip Ježowicz, Radek Melša.

Úvodní několikaminutová, fyzická náročná ilustrace gesticko-mimické herecké techniky umocněná prvky tance a pantomimy. Mejercholdova biomechanika. Jako základ scény jednoduchost, a to $\mathrm{v}$ režijních stavebních prvcích: schody, plošiny, zástěny i žebříky. Jeviště ve stejné úrovni jako hlediště: oba prostory jsou propojené.

Taková je demonstrace podstatných principů zmíněného autorského experimentálního divadla, a to hned $\mathrm{v}$ úvodu představení, které vzniklo především prací dvojice kreativních osobností Jakuba Kostelníka (autora scénáře) a J. A. Pitínského (režiséra) v představení Mejerchold. Diváka neznalého Mejercholdova divadelního jazyka překvapí, všechny zaujme a strhne.

Hned po úvodu se přidává uplatnění dalšího učebnicově známého principu: extrémní rytmizace řeči. Realizace Mejercholdova specifického divadelního jazyka, která nás pak provází téměř po celou dobu představení, je téměř úplná.

Vzápětí se též divák stává spolutvůrcem divadla (tedy tím, kdo dotváří scénické významy), ačkoli to patří $\mathrm{k}$ obtížné složce každého představení, nejen $\mathrm{z}$ realizace Mejercholdových principů. Pokusů o aktualizaci je však jen několik málo a nevyznívají vždy přesvědčivě, navíc sklouzávají v případě několika hereckých replik k tzv. laciným efektům. („Koho máš jako herce rád? Já Lišku.") 
Konstatujme ale hned, že právě uvedené patří k našim ojedinělým drobným výhradám $k$ jinak výjimečně zdařilému představení. Snad ještě kromě toho, že někteří herci mohli více zapracovat na svém cizojazyčném projevu (Mejecholdova postava mluví v dětství německy s matkou, Mejercholdovo rodinné židovské zázemí bylo totiž, jak známo, jazykově jak ruské, tak německé; v představení zazní opakovaně i ruština). Celkově ovšem nutno konstatovat, že výkon herců je strhující.

Ale pokračujme - alespoň v deskripci recenzovaného představení - postupně. Záměrem invenčního rusisty a teatrologa Jakuba Kostelníka $\left({ }^{*} 1982\right)$ totiž bylo zachytit umělecký vývoj Vsevoloda Emiljeviče Mejercholda (1874-1940); ruského avantgardního režiséra, herce, zakladatele ruského stylizovaného divadla i jeho teoretika $\mathrm{v}$ zásadě chronologicky: od role herce ovlivněného $\mathrm{v}$ počátcích (o jedenáct let starším) Konstantinem Stanislavským (divadelním režisérem a pedagogem), přes ilustraci Mejercholdovy tzv. psychologické metody až k samostatnému uměleckému pojetí divadla. Chronologicky jsou současně reflektovány podstatné momenty Mejercholdova života, a to $\mathrm{v}$ dětství a jinošství ovlivněných despotickým otcem, poté nezměrnou touhou obětovat se divadlu jako herec a režisér, přes její realizaci zčásti zasaženou jeho sympatizováním se sovětským režimem, ale jako umělce, který se vyhranil svým svobodným invenčním pojetím, a nakonec za to $\mathrm{v}$ době stalinského kultu krutě potrestán (popravou zastřelením).

V linii Mejercholdova uměleckého vývoje se představují výběrově klíčové autority tehdejšího kulturního života, a to až formou miniportrétů (zejména Jesenin). Postava Antona Pavloviče Čechova je zdařile profilována inscenováním režijní práce na jeho hře Racek, v níž Mejerchold jako herec ztělesnil postavu Trepleva. V této souvislosti se ukazuje Mejercholdova (i Čechovova) polemika s divadelním pojetím Konstantina Stanislavského, zvýrazněna je i jeho nefunkčnost dlouhé pauzy (nehledě na to, je vztah Stanislavského a Mejercholda ukázán plasticky: Stanislavský chtěl Mejercholdovi nabídnout práci režiséra v operním divadle, když to Mejercholdovo vlastní bylo v roce 1938 uzavřeno, kvůli Stanislavského náhle smrti se to však už neuskutečnilo). Vladimír Majakovský je ztělesněn ve své pověstné žluté košile a deklamován je úryvek z jeho poemy 150 oooo (a ne z inscenace Mystéria-buffa, kterou Mejerchold opakovaně inscenoval); Alexandr Blok se spíše mihne v úvahách o možném inscenování jeho poemy 12, jehož nebezpečí si byl Mejerchold vědom (vždyt̉ poema končí verši, že před 12 rudoarmějci poemy kráčí kulkou nezasažitelný s věncem bílých růží na hlavě Ježíš Kristus).

Z hlediska uvedených miniportrétů je Mejercholdův příběh pozdržen zejména profilováním postavy Sergeje Jesenina (ve své době v recepci prvním básníkem Ruska), která zpívá na motivy básníkova známého textu (Dopis matce). S osobností Mejercholda je ale Jesenin spojen $\mathrm{v}$ dynamické zkratce svého vztahu s Isadorou Duncanovou (americkou levicově zaměřenou tanečnicí, která $s$ Jeseninem necelé 
tři roky s přestávkami jako jeho třetí manželka žila). Jejich vztah je inscenován dynamickým tanečním sólem Duncanové, v jeho závěru s červenou stuhou Jesenina obepínající. Tryská z něj jak fyzično, tak tvůrčí energie, a předjímá implicitně i jeho tragičnost (Jesenin jako tehdejší v Rusku tolik uznávaný básník v zahraničí nesl těžce svou druhořadou roli vedle známé Duncanové; ve světových jazycích si údajně dokázal pouze objednat alkohol). Další část představení je založena na vybraných výsecích z několika typů Mejercholdových představení: výraznější časový úsek zabírá ukázka inscenace pohádky Láska ke třem pomerančưm ${ }^{1}$ (velmi volné zpracování s východiskem v dramatu Carla Gozziho, původně Mejercholdem inscenovaného roku 1913 v jeho experimentálním Studiu v Borodinské ulici v Petrohradě) a dále napr. ukázka z inscenace Lermontovova dramatu Maškaráda (inscenovaným roku 1917 v Alexandrinském divadel v Petrohradě). V závěru představení je to zkouška z Mejercholdovy inscenace Dámy s kaméliemi Al. Dumase ml. (v originále řazená $\mathrm{k}$ Mejercholdovu tzv. impresionistickému a výpravnému období) v roce 1934. Zobrazení Mejercholdovy postavy v bílé košili potřísněné rudou barvou v křečích nadlidského výkonu dotáhnout $\mathrm{i}$ toto představení v práci s hercem $\mathrm{k}$ dokonalosti už předjímá bolestný konec dosud úplně nedoceněného avantgardního režiséra.

Autor scénáře Jakub Kostelník, vystudovaný nadaný rusista a teatrolog, ale též nadaný básník i překladatel napsal velmi podnětný text, a to i na základě Mejercholdovy korespondence a málo známých materiálů. Podařilo se mu vystihnout to podstatné: Mejercholdův prínos, a to i pro dnešní divadelní umění. Vzhledem $\mathrm{k}$ jeho odkazu si počínal nejen invenčně, ale i zčásti volně, když miniportréty ruských autorů ilustroval jejich typickými texty (a to i bez př́mého vztahu inscenovaných $\mathrm{k}$ Mejercholdovi).

Režisér představení J. A. Pitínský ( ${ }^{*} 1955$, vl. jménem Zdeněk Petrželka, nositel několika ocenění Alfréda Radoka) dokázal herce dovést $\mathrm{k}$ výkonu Mejercholdovu odkazu hodnému. Jeho prolínání různých stylů (prvky pantomimy, realismu, surrealismu) a jejich dotváření je kreativní a ve svém komplexnosti (i díky záznamům Mejercholdových př̀edstavení) inscenaci umocňuje. Začínající dramaturg Libor Brzobohatý se už v daném představení též projevil jako talentovaný. Jeho invenční spolupř́nos je patrný zejména $\mathrm{z}$ aktualizace a domýšlení Mejercholdovy inscenace Gogolova Revizora, a to ve vymyšleném, výrazně erotickém snu Anny Andrejevny.

Nezbývá než v ocenění konkretizovat ještě nejprve výkony herců. Jsou (a to i díky vynikající pohybové spolupráci Adamy Mašury) vesměs precizní, a vyrovnané. Zmiňme za všechny nejprve alespoň herecké ztvárnění Mejercholda Johnnym Horákem, který stejně jako ostatní začínající herci dokonale ilustruje Mejercholdův

1 Za identifikaci pohádky jako Láska ke třem pomerančům a za zpřesnění tvůrčího přínosu vzhledem k inscenování Gogolova Revizora (viz v dále v textu) jsem povinována poděkováním autoru předlohy Jakubu Kostelníkovi. 
divadelní jazyk nejen svým pohybem (zpravidla po špičkách), ale až křečovitým vyjádřením silných emocí. Autorsky, režijně i dramaturgicky je inovativně pojata zejména postava Wolanda (Radek Melša), který de facto v roli dábla z Bulgakovova románu Mistr a Markétka v inscenaci figuruje jako nejen vypravěč (který scény uvádí, ale i komentuje), ale i jako alter ego hlavní postavy.

Konečně třeba zmínit i promyšlenou práci s kostýmy invencí Magdalény Paráčkové-Teleky. Patř́ k ní nejen střídání jejich úborů v závislosti jak na roli, kterou představují, tak současně na reflexi její životní i divadelní etapy i ilustrace Mejercholdova typu inscenace s realizací symbolické barvy (bílé šortky dítěte, červený oblek muže sympatizujícího se sovětským režimem [STAROVÁ 2020]).

K dynamickému i významovému vyznění inscenace přispívá i promyšlená práce se světly: nejen jejich zhasínáním a rozžínáním, ale i blikáním či tzv. problikáváním. Graduje v závěru, kdy je světelný kužel zaměřen na hlavní postavu a je tak symbolicky ztvárněn její odchod ze života do světla na konci tunelu. Celek konečně podkreslují promyšlené hudební efekty (vzniklé prací Richarda Dvořáka).

Principy Mejercholdova divadelního jazyka byly díky vyrovnané spolupráci tvůrčího týmu umocněny (dokonce i dokresleny dobovou projekcí) a aktualizovány perfektními a vyrovnanými výkony začínajících herců, kteří svým plným nasazením odvedli nesmírně náročný fyzický a intelektuální výkon. Díky recenzovanému představení jsme nejen $\mathrm{v}$ roli diváků opět uvěřili, že divadlo mủže intenzivně promlouvat bez ohledu na naši divadelní poučenost, kompetence i odlišné politické názory.

\section{Bibliografie:}

STAROVÁ, V. (2020): Mejerchold: bio(mechanika). <https://krith.phil.muni.cz/recenze/ mejerchold-biomechanika>. [online]. [cit. 27. 3. 2020].

\section{Summary \\ Exceptional Theatrical Achievement Mejerchold (Performance by Theatre Studio Marta of the Janáček Academy of Music and Performing Arts Brno)}

The review covers a performance by Mejerchold in the wider context of Russian cultural realities. The staging is valued as exceptionally accomplished, creative and inspirational. In this context, the screen play by J. Kostelník and the direction by J. A. Pitinský is higly appreciated. The performance of the actors, the work of playwright by R. Dvořák and the costume by designer M. Paráčková-Teleky are 
excellent. In relation to Russian realities, de facto cultural branches are also being cretaed in a creative way, especially towards the personality of S. Jesenin, more integrally towards the personality of Mejerchold A.P. Čechov. The performance as a whole shows an above-standard and creative level. Mejerchold's contribution is amplified. Thanks to reviewed performance is again to believe that culture is still I indisppensable and stimulating.

\section{About the author}

Michaela Hashemi, Masaryk University, Faculty of Arts, Department of Czech Literature, Brno, Czech Republic, Michaela.Soleiman-pour-Hashemi@seznam.cz 
